\title{
Soil Carbon Dynamics in Corn-Based Agroecosystems: Results from Carbon-13 Natural Abundance
}

\author{
H. P. Collins, R. L. Blevins, L. G. Bundy, D. R. Christenson, W. A. Dick, D. R. Huggins, and E. A. Paul*
}

\begin{abstract}
We used natural ${ }^{13} \mathrm{C}$ abundance in soils to calculate the fate of $\mathrm{C}_{5}-\mathrm{C}$ inputs in fields cropped to continuous corn (Zea mays $\mathbf{L}$.). Soil samples were collected from eight cultivated and six adjacent, noncultivated sites of the Corn Belt region of the central USA. The amount of organic $C$ in cultivated soils declined an average of $68 \%$, compared with adjacent, noncultivated sites. The $\delta{ }^{13} \mathrm{C}$ of cultivated soil profiles that had been under continuous corn for 8 to 35 yr increased in all depth increments above that of the noncultivated profiles. The percentage of soil organic $\mathrm{C}$ (SOC) derived from corn residues and roots ranged from 22 to $40 \%$ of the total $C$. The proportion of corn-derived $\mathbf{C}$, as determined by this technique, decreased with soil depth and was minimal in the $50-$ to $100-\mathrm{cm}$ depth increments of fine-textured soils. The mean residence time of the non-corn $\mathrm{C}$ $\left(C_{3}\right)$ ranged from 36 to $108 \mathrm{yr}$ at the surface, and up to $769 \mathrm{yr}$ at the subsoil depth. The longer turnover times were associated with soils high in clay. Prairie-derived soils have a higher potential to sequester $\mathrm{C}$ than those derived from forests. The significant loss of total $\mathrm{C}$ at all sites and the slow turnover times of the incorporated $C$ lead us to conclude that there is a substantial potential for soils to serve as a $\mathrm{C}$ sink and as a significant nutrient reserve in sustainable agriculture.
\end{abstract}

$S^{\text {o }}$ IL ORGANIC CARBON is a major controller of soil tilth and fertility that reflects and influences ecosystem processes. Agriculture reduces SOC levels and contributes to increases in atmospheric $\mathrm{CO}_{2}$ concentrations (Houghton et al., 1983). Altered management practices such as reduced tillage, decreased bare fallow, and increased residue inputs not only mitigate the loss of C, but in some cases can also increase soil $\mathrm{C}$ levels (Paustian et al., 1997; Flach et al., 1997). The significance of soil $\mathrm{C}$ pools and fluxes in global change scenarios and sustainable agriculture require that data for specific sites be related to landscape and regional scales.

Atmospheric $\mathrm{CO}_{2}$ contains both radioactive $\left({ }^{14} \mathrm{C}\right)$ and stable $\left({ }^{13} \mathrm{C}\right)$ isotopes suitable for tracer studies. These are incorporated into plants by photosynthesis and eventually into soils through decomposition and humifi-

H.P. Collins and D.R. Christenson, Dep. of Crop and Soil Sciences, Michigan State Univ., East Lansing, MI 48824-1325; H.P. Collins, present address: 7535 Mesplay Avenue SE, Lacey, WA 98503; R.L. Blevins, Agronomy Dep., Univ. of Kentucky, Lexington, KY 405460091; L.G. Bundy, Dep. of Soil Science, Univ. of Wisconsin, Madison, WI 53706-1299; W.A. Dick, School of Natural Resources, The Ohio State Univ., Wooster, OH 44691; D.R. Huggins, Southwest Experiment Station, Univ. of Minnesota, Lamberton, MN 56152; E.A. Paul, Dep. of Crop and Soil Sciences, Michigan State Univ., East Lansing, MI 48824-1325. Received 20 June 1997. *Corresponding author (paulea@pilot.msu.edu).

Published in Soil Sci. Soc. Am. J. 63:584-591 (1999). cation. Studies involving ${ }^{13} \mathrm{C}$ abundance have been used to measure vegetation shifts (Galimov, 1985; Cerri and Andreux, 1990), community composition (Dzurec et al., 1985), soil chronosequence analyses (Stout et al., 1981; Guillet et al., 1988), root growth and respiration (Qian and Doran, 1996; Gregorich et al., 1996), SOC turnover (Balesdent et al., 1988), and microbial biomass turnover (Ryan and Aravena, 1994). The isotope signal in the plant is retained essentially unchanged in the SOC (Wedin et al., 1995; Boutton, 1996).

Plant C isotope ratios vary somewhat during the growing season (Tieszen and Steuter, 1991) and are affected by moisture (van Kessel et al., 1994). Martel and Paul (1974) found that the soils of low, moist areas (gleysols) can be $2 \%$ more negative than associated upland mollisols of the catena.

Production of wheat (Triticum aestivum L.) for 100 yr on a $\mathrm{C}_{3}-\mathrm{C}_{4}$ prairie of the Sanborn plots in Missouri, with an original $\delta{ }^{13} \mathrm{C}$ of $-18.6 \%$, resulted in replacement of $50 \%$ of the SOC by the residue from the agricultural crop (Balesdent et al., 1988). A Colorado site cultivated to wheat for $84 \mathrm{yr}$ had a ${ }^{13} \mathrm{C}$ content of $-19.3 \%$ 。 compared with $-16.1 \%$ for adjacent native vegetation (Follett et al., 1997). Thus, $30 \%$ of its SOC was derived from wheat residues; the remaining $70 \%$ was from SOC present before cultivation. Calculation of the aboveand belowground $\mathrm{C}$ inputs from wheat and associated weeds showed a residue incorporation efficiency of $5 \%$ into SOC during the period of 1909 to 1993 period. A nearby Nebraska site, cultivated with wheat for $22 \mathrm{yr}$, had $17 \%$ of its soil organic matter (SOM) derived from wheat. This represented an incorporation efficiency of $10.5 \%$ (Follett et al., 1997).

Analysis of soil that had grown $\mathrm{C}_{4}$ corn for $25 \mathrm{yr}$ on an original $\mathrm{C}_{3}$ forested site $(-28.2 \%$ ) in Ontario, Canada allowed Gregorich et al. (1995) to determine that 30\% of the SOC in the $0-$ to $30-\mathrm{cm}$ layer came from corn. This represented a mean residence time of $35 \mathrm{yr}$ for the non-corn-derived C. Monreal (personal communication, 1998) combined ${ }^{14} \mathrm{C}$ and ${ }^{13} \mathrm{C}$ analyses to determine that the organic $\mathrm{C}$ of macroaggregates turned over in $61 \mathrm{yr}$, while that in microaggregates required $275 \mathrm{yr}$.

Extrapolation of site-specific SOC turnover data to other soils and modeling of regional input parameters can only be accomplished using multiple sites with a known history of management and crop residue inputs. A series of long-term agricultural sites from Kentucky

Abbreviations: KBS, Kellogg Biological Station; MRT, mean residence time; SOC, soil organic C; SOM, soil organic matter. 
Table 1. Soil series, classification, texture, and parent material by location.

\begin{tabular}{|c|c|c|c|c|c|c|c|}
\hline \multirow[b]{2}{*}{ Site } & \multirow[b]{2}{*}{ Location } & \multirow[b]{2}{*}{ Soil series and texture } & \multirow[b]{2}{*}{ Classification } & \multicolumn{3}{|c|}{ Fraction $<2 \mathrm{~mm}$} & \multirow[b]{2}{*}{ Parent material } \\
\hline & & & & Sand & Silt & Clay & \\
\hline & & & & & $\%$ & - & \\
\hline Lamberton, $\mathbf{M N}$ & $44^{\circ} 14^{\prime} \times 95^{\circ} 18^{\prime} \mathrm{W}$ & Normania loam & Typic Haplustoll & 31 & 42 & 27 & glacial till \\
\hline Arlington, WI & $43^{\circ} 18^{\prime}$ N $89^{\circ} 21^{\prime} W$ & Plano silt loam & Typic Argiudoll & 10 & 68 & 22 & loess, glacial till \\
\hline Saginaw, MI & $43^{\circ} 23^{\prime} \times 84^{\circ} 07^{\prime} W$ & Misteguay silty clay & Aeric Haplaquept & 9 & 44 & 47 & lacustrine \\
\hline \multirow{6}{*}{$\begin{array}{l}\text { Hickory Corners, MI } \\
\quad \text { Kellogg Biological Sta. } \\
\text { Hoytville, OH } \\
\text { Wooster, OH } \\
\text { South Charleston, OH } \\
\text { Lexington, KY }\end{array}$} & & & & & & & \\
\hline & $42^{\circ} 18^{\prime} \mathrm{N} 85^{\circ} 30^{\prime} \mathrm{W}$ & Kalamazoo loam & Typic Hapludalf & 43 & 38 & 19 & glacial outwash \\
\hline & $41^{\circ} 00^{\prime} \mathrm{N} 84^{\circ} 00^{\prime} \mathrm{W}$ & Hoytville silty clay loam & Mollic Ochraqualf & 21 & 42 & 37 & lacustrine \\
\hline & $40^{\circ} 48^{\prime} \times 82^{\circ} 00^{\prime} \mathrm{W}$ & Wooster silt loam & Typic Fragiudalf & 25 & 60 & 15 & glacial till \\
\hline & $39^{\circ} 48^{\prime}$ N $83^{\circ} 30^{\prime} \mathrm{W}$ & Crosby silt loam & Aeric Ochraqualf & 15 & 65 & 20 & glacial till \\
\hline & $38^{\circ} 07^{\prime}$ N $84^{\circ} 29^{\prime} W$ & Maury silt loam & Typic Paleudalf & 7 & 70 & 23 & phosphatic limestone \\
\hline
\end{tabular}

to Minnesota have grown continuous corn for 8 to 35 yr (Paul et al., 1997). These sites have well-documented grain yields and management practices that make it possible to calculate the contribution of above- and beneath-ground crop residues. Our objectives were: (i) to calculate the contribution of corn residues to SOC contents, (ii) to determine mean residence time (MRT) of the non-corn-derived $\mathrm{C}$ relative to climate and soil type, and (iii) to determine the fate of corn residues on a variety of soil types with long-term management records.

\section{MATERIALS AND METHODS}

We sampled eight long-term agricultural experimental sites within the Corn Belt of the USA (Table 1). The climate is continental, with cool moist winters and hot humid summers. Mean annual temperatures range from $6.2^{\circ} \mathrm{C}$ in the northwestern portion (Lamberton, $\mathrm{MN}$ ) to $13^{\circ} \mathrm{C}$ in the south (Lexington, KY). The frost-free period ranges from 140 to $175 \mathrm{~d}$. Growing season precipitation is $630 \mathrm{~mm}$ in the northern and $1140 \mathrm{~mm}$ in the southern Corn Belt. The majority of soils were formed in glacial deposits (till, lake sediments or loess overlying glacial till). The soil at Lexington, KY was formed in residuum composed of phosphatic limestone. Native vegetation of the eastern sites was a mixed, deciduous hardwood forest $\left(\mathrm{C}_{3}\right.$ photosynthetic pathway) cleared for agriculture in the mid 1850s. Native grasslands at Lamberton, $\mathrm{MN}$ and Arlington, WI contained both $C_{3}$ and $C_{4}$ species and were first plowed in the late 1870s.

The sites had nearly all been in continuous corn for 8 to 35 yr. The rotation at Saginaw, MI includes $C_{3}$ sugar beet (Betula vulgaris $\mathbf{L}$.) once in a 4-yr rotation (corn-corn-cornsugar beet). The beet crop leaves very little residue. Rotations at the Kellogg Biological Station (KBS) in southwest Michigan before 1960 were forage and small grains. From 1960 to 1970 the rotation was $3 \mathrm{yr}$ of alfalfa (Medicago sativa L.), $1 \mathrm{yr}$ of corn, and $1 \mathrm{yr}$ of soybean (Glycine $\max \mathrm{L}$.). From 1970 to 1984 the rotation was corn-soybean-wheat. From 1985 to time of sampling it was continuous corn. The Ohio sites had been in grass meadow for $6 \mathrm{yr}$ before planting to corn in 1962. The Lexington, KY site had been in bluegrass (Poa pratensis $\mathbf{L}$.) for $50 \mathrm{yr}$ before the start of the experiment in 1970. Rotations at the prairie sites before 1950 included corn-soybean and small grain production. All cultivated sites were fertilized with inorganic $\mathrm{N}$ and had corn residues incorporated by inversion tillage (Paul et al., 1997).

We used the harvest index for each site (Vanotti et al., 1997; Huggins and Fuchs, 1997; Christenson, 1997; Dick et al., 1997; Frye and Blevins, 1997) to estimate aboveground corn residues. Roots were estimated by assuming an aboveground crop residue/root ratio of 1:0.54 (Buyanovsky et al., 1987; Buyanovsky and Wagner, 1997; Follett et al., 1997). Weed C inputs were estimated as 0.25 times the sum of straw plus root
C inputs (Greb, 1983; Follett et al., 1997). We assumed that $50 \%$ of the weed biomass was $\mathrm{C}_{4}$. Aboveground plant residues were estimated to be $40 \% \mathrm{C}$ on a dry weight basis and roots $38 \%$ C (Parr and Papendick, 1978).

Sites were sampled following harvest in 1993, except for Lexington, $\mathrm{KY}$ and Lamberton, $\mathrm{MN}$, which were sampled in the fall of 1992. Five of the cultivated sites, Arlington, WI; Kellogg Biological Station, MI; Hoytville, $\mathrm{OH}$; Wooster, OH; and Lexington, $\mathrm{KY}$ had adjacent noncultivated areas that were sampled in the fall of 1995. For Lamberton, MN, the closest remnant prairie was located near Brownton, MN. Although the site was $97 \mathrm{~km}$ west of Lamberton, it occurred on the same soil type and landscape position. The prairie site at Arlington, WI occurred at an upland position, while the cropped treatment occupied a landscape position typical of most of the prairie-derived soils in the area. Six cores $(5.4 \mathrm{~cm}$ in diameter by $1 \mathrm{~m}$ long) were collected from each cultivated field replicate. There were four field replicates at all sites, except for those in Ohio which had three. The adjacent noncultivated sites were not replicated; triplicate field samples were collected to determine site variability. Before compositing, each core was divided into four increments; 0 to 20,20 to 25 , 25 to 50 , and 50 to $100 \mathrm{~cm}$. The $20-$ to $25-\mathrm{cm}$ depth increment is not discussed in this paper. Bulk density was determined from the mass of soil (oven-dry basis) and the core volume.

Soil samples were sieved moist to pass a 2-mm screen and recognizable plant fragments were removed. The soil was air dried, and stored in plastic bags. Soil carbonates were removed by adding $100 \mathrm{~mL}$ of $0.25 \mathrm{M} \mathrm{HCl}$ to $20 \mathrm{~g}$ of soil and shaking for $1 \mathrm{~h}$. Soils were washed three times with deionized water to remove excess $\mathrm{Cl}^{-}$, centrifuged, dried at $55^{\circ} \mathrm{C}$, and ground to pass a $180-\mu \mathrm{m}$ screen. Total soil $\mathrm{C}$ and $\delta{ }^{13} \mathrm{C}$ were determined on a Europa Model 2020, continuous-flow mass spectrometer with a triple collector (Europa Scientific, Crewe, England). Each analysis was the mean of duplicate subsamples. Working standards for ${ }^{13} \mathrm{C}$, sugar beet sucrose $(-25.68 \%$ V-PDB $)$ and sugar cane $(-10.45 \%$ V-PDB) were calibrated against NBS$22(-29.74 \%$ V-PDB) and ANU sucrose (IAEA-C-6, $-10.43 \% \mathrm{~V}-\mathrm{PDB}$ ). Two reference samples were included after every 12 soil samples. Multiple analyses of the reference sample yielded a standard deviation of $0.05 \%$.

We calculated the change in the fraction of SOC resulting from conversion to a monoculture of $\mathrm{C}_{4}$ corn using the equation:

$$
\begin{aligned}
& \% \text { of } \mathrm{C} \text { derived from corn }= \\
& \frac{\delta{ }^{13} \mathrm{C} \text { cropped soil }-\delta{ }^{13} \mathrm{C} \text { native soil }}{\delta{ }^{13} \mathrm{C} \text { corn }-\delta{ }^{13} \mathrm{C} \text { native soil }}
\end{aligned}
$$

The $\delta{ }^{13} \mathrm{C}$ of corn stover was determined for triplicate samples collected across the site network.

We used an exponential decay equation to determine the turnover rate of the $\mathrm{C}_{3}-\mathrm{C}$ within each horizon: $A_{\mathrm{t}}=$ $A_{0}\left(\exp ^{-k t}\right)$, where $A_{0}$ is the amount of $\mathrm{C}_{3}-\mathrm{C}$ prior to the 
Table 2. Initial soil $\mathrm{C}$ contents prior to long-term corn monoculture.

\begin{tabular}{lcc}
\hline Site & Year sampled & Soil C $\dagger$ \\
\hline & & $\mathrm{Mg} \mathrm{C} \mathrm{ha}^{-1}$ \\
Lamberton, MN & 1978 & $\mathbf{7 1 . 5}$ \\
Arlington, WI & 1958 & $\mathbf{5 6 . 6}$ \\
Saginaw, MI & 1972 & 44.3 \\
Hoytville, OH & 1962 & 59.8 \\
Wooster, OH & 1962 & 37.0 \\
Lexington, KY & 1970 & 42.3 \\
\hline
\end{tabular}

$\uparrow$ Values obtained from Paul et al. (1997).

corn monoculture, $A_{\mathrm{t}}$ is the amount of $\mathrm{C}_{3}-\mathrm{C}$ remaining after replacement by $\mathrm{C}_{4}-\mathrm{C}$ vegetation (corn), $k$ is the decay constant, and $t$ is the time in continuous corn. Initial soil $C$ contents to $20 \mathrm{~cm}$ before the corn monoculture are presented in Table 2. We assumed that the $\delta{ }^{13} \mathrm{C}$ of the initial soil samples was similar to that of the associated noncultivated site, since most sites had been cropped to hay, forages, and small grains (alfalfa and wheat have an average $\delta{ }^{13} \mathrm{C}$ of $-26.5 \%$ ) before the corn monoculture.

\section{RESULTS AND DISCUSSION}

\section{Carbon Inputs}

Long-term corn yields ranged from $6.8 \mathrm{Mg} \mathrm{ha}^{-1} \mathrm{yr}^{-1}$ at Wooster, $\mathrm{OH}$ to $7.8 \mathrm{Mg} \mathrm{ha}^{-1} \mathrm{yr}^{-1}$ at Arlington, WI (Table 3). This equivalency of yields is related to the similarity of management practices used in the production of corn in the north-central USA. Inputs of aboveground corn residues ranged from $3.3 \mathrm{Mg} \mathrm{C} \mathrm{ha}^{-1}$ $\mathrm{yr}^{-1}$ at Lamberton, $\mathrm{MN}$ to $4.3 \mathrm{Mg} \mathrm{Cha}^{-1} \mathrm{yr}^{-1}$ at Lexington, $\mathrm{KY}$, reflecting the increase in harvest index from southern to northern sites. Our estimate of the contribution of root $\mathrm{C}$ ( $54 \%$ of the aboveground residue input) is considered to be a minimum since it was based on the recovery of roots by mechanical methods. In a ${ }^{14} \mathrm{C}$ labeling study, Buyanovsky et al. (1987) reported that total production of root $\mathrm{C}$ for wheat, including exudates and sloughed root materials, could be 40 to $50 \%$ greater than root yields obtained by wet sieving. Total annual $\mathrm{C}$ inputs averaged $7.7 \mathrm{Mg} \mathrm{C} \mathrm{ha}{ }^{-1} \mathrm{yr}^{-1}$.

\section{Soil Organic Carbon}

The noncultivated sites show the influence of soil type and vegetation on SOC reserves. These ranged from 68
$\mathrm{Mg} \mathrm{C} \mathrm{ha} a^{-1}$ at the forested KBS, MI site to $186 \mathrm{Mg} \mathrm{C}$ $\mathrm{ha}^{-1}$ in the prairie-derived soil in Minnesota (Table 4). Cultivation decreased profile $\mathrm{C}(0-50 \mathrm{~cm})$ by $16 \mathrm{Mg} \mathrm{C}$ $\mathrm{ha}^{-1}$ at KBS, MI; $32 \mathrm{Mg} \mathrm{C}^{-1}$ at Wooster, $\mathrm{OH}$; and $48 \mathrm{Mg} \mathrm{C}$ ha ${ }^{-1}$ at Hoytville, OH. At Lexington, $\mathrm{KY}, 23$ yr of continuous corn reduced profile $\mathrm{C}$ by $48 \%$. At Lamberton, MN, soil samples collected in 1978 showed a $30 \%$ decrease in soil $\mathrm{C}$ in the 0 - to $20-\mathrm{cm}$ depth increment after 108 yr of cultivation. By 1992, soil C had decreased an additional $25 \mathrm{MgC} \mathrm{ha}{ }^{-1}$, resulting in a total C loss of $53 \%$ since conversion. Samples collected at Arlington, WI in both 1958 and 1992 showed similar SOC loss of $18 \%$ relative to the noncultivated site.

\section{Carbon-13 Values of Plant Materials and Soil}

The $\delta{ }^{13} \mathrm{C}$ values of forest plant materials at KBS, MI were $-27.5 \%$ for oak (Quercus rubra L.) leaves and $-26.5 \%$ for oak bark (Table 5). Corn stover ranged from $-12.0 \%$ to $-12.4 \%$. The $\delta{ }^{13} \mathrm{C}$ profiles of the cultivated soils differed considerably from the noncultivated sites (Table 6). The $\delta{ }^{13} \mathrm{C}$ values within the soil profile of the prairie remnant at Arlington, WI ranged from $-17.6 \%$ at the surface to $-18.2 \%$ at $1 \mathrm{~m}$. The prairie soil at Brownton, MN showed only a small increase $(0.5 \%)$ in $\delta{ }^{13} \mathrm{C}$ with depth. The $1.9 \%$ difference in $\delta$ ${ }^{13} \mathrm{C}$ between Arlington, WI and Brownton, $\mathrm{MN}$ indicates a greater proportion of the soil $\mathrm{C}$ at Arlington was of $\mathrm{C}_{4}$ origin (60 vs. $47 \%$ ). Huggins et al. (1998) reported $45 \% \mathrm{C}_{4}$-derived $\mathrm{C}$ at the Brownton prairie.

The $\delta{ }^{13} \mathrm{C}$ values of the noncultivated forested sites ranged from -25 to $-26.1 \%$ at the surface and increased an average of $1.2 \%$ with depth, except for Hoytville, $\mathrm{OH}$ which showed a $1.3 \%$ o decrease to $1 \mathrm{~m}$ (Table 6). The increase in ${ }^{13} \mathrm{C}$ with depth (1.4\%) is typical of welldrained soils (Balesdent and Balabane, 1992; Balesdent et al., 1993; Gregorich et al., 1995). This $\delta{ }^{13} \mathrm{C}$ increase with depth is probably due to fractionation during decomposition, which increases as mean age of soil $\mathrm{C}$ increases with depth (Agren et al., 1996). The younger soil $\mathrm{C}$ near the surface may also be more depleted in $\delta$ ${ }^{13} \mathrm{C}$ because of the -1.2 to $-1.5 \%$ change in the atmosphere due to the release of $\mathrm{CO}_{2}$ from the burning of fossil fuels (Balesdent and Mariotti, 1996). The cause of the unusual decrease in soil ${ }^{13} \mathrm{C}$ with depth observed at

Table 3. Cumulative grain yield and estimated residue, root, and weed $\mathrm{C}$ inputs into cultivated soils cropped to continuous corn.

\begin{tabular}{|c|c|c|c|c|c|c|c|c|}
\hline Site & $\begin{array}{c}\text { Years } \\
\text { cropped } \\
\text { to corn }\end{array}$ & $\begin{array}{c}\text { Cumulative } \\
\text { grain } \\
\text { yield } \dagger \\
\end{array}$ & HI & Residue & Roots & Weeds & Total & $\begin{array}{c}\text { Annual } \\
\text { total }\end{array}$ \\
\hline & $\mathbf{y r}$ & $\mathrm{Mg} \mathrm{ha}^{-1}$ & & \multicolumn{4}{|c|}{ — $\mathrm{Mg} \mathrm{ha}^{-1}$} & $M g C h a^{-1} y^{-1}$ \\
\hline Lamberton, MN & $\mathbf{3 3}$ & $\mathbf{2 4 0 . 7}$ & 0.47 & 108.6 & 58.8 & 41.8 & 209.2 & 6.3 \\
\hline Arlington, WI & 35 & 272.1 & $\mathbf{0 . 4 3}$ & 144.3 & 78.1 & 55.6 & 278.0 & 7.9 \\
\hline Saginaw, Ml & 16 & 108.7 & 0.42 & 61.3 & $\mathbf{3 3 . 2}$ & 23.6 & 118.1 & 7.4 \\
\hline KBS, MI§ & 8 & 56.8 & 0.42 & 31.4 & $\mathbf{1 7 . 0}$ & 12.1 & 60.5 & 7.6 \\
\hline Wooster, OH & 31 & 209.6 & $\mathbf{0 . 4 2}$ & 115.8 & 62.7 & 44.6 & 223.1 & 7.2 \\
\hline Hoytville, OH & 31 & 235.6 & 0.42 & 130.1 & 70.5 & 50.2 & 250.8 & 8.1 \\
\hline South Charleston, OH & 31 & 232.7 & 0.41 & 134.0 & 71.0 & 50.5 & 252.4 & 8.1 \\
\hline Lexington, $\mathrm{KY}$ & 23 & 163.3 & 0.41 & 94.0 & 50.9 & 36.2 & 181.1 & 7.9 \\
\hline
\end{tabular}

† Grain yields obtained from Paul et al., 1997.

¥ HI is harvest index. Below ground root estimates were based on an aboveground crop residue/root ratio of 1:0.54 (Buyanovsky et al., 1987; Buyanovsky and Wagner, 1996; Follett et al., 1997). Weed C inputs were estimated as 0.25 (Greb, 1983; Follett et al., 1997). Aboveground plant residues were assumed to be $40 \% \mathrm{C}$ on a dry-weight basis and roots 38\% C (Parr and Papendick, 1978).

$\S$ KBS is Kellogg Biological Station. 
Table 4. Bulk density and organic soil $\mathrm{C}$ for the 0 - to 20-, 25- to 50-, and 50- to 100-cm depth increments of noncultivated and cultivated sites.

\begin{tabular}{|c|c|c|c|c|c|}
\hline \multirow[b]{2}{*}{ Site } & \multirow[b]{2}{*}{ Depth } & \multicolumn{2}{|c|}{ Noncultivated } & \multicolumn{2}{|c|}{ Cultivated } \\
\hline & & Bulk density & Soil C & Bulk density & Soil C \\
\hline & cm & $\mathrm{Mg} \mathrm{m}^{-3}$ & $\mathrm{MgCh} \mathbf{h a}^{-1}$ & $\mathrm{Mg} \mathrm{m}^{-3}$ & $\mathrm{MgC} \mathrm{ha} \mathbf{C}^{-1}$ \\
\hline Lamberton, $\mathbf{M N} \dagger$ & $\begin{array}{c}0-20 \\
25-50 \\
50-100\end{array}$ & $\begin{array}{l}0.92(0.07) \ddagger \\
1.39(0.03) \\
1.52(0.14)\end{array}$ & $\begin{array}{r}100.2(3.7) \\
53.4(2.5) \\
32.6(1.6)\end{array}$ & $\begin{array}{l}1.32(0.04) \\
1.55(0.13) \\
1.55(0.05)\end{array}$ & $\begin{array}{l}46.7(2.2)^{* * *} \\
32.2(1.2)^{* *} \\
33.1(0.2)\end{array}$ \\
\hline Arlington, WI & $\begin{array}{c}0-20 \\
25-50 \\
50-100\end{array}$ & $\begin{array}{l}1.30(0.03) \\
1.41(0.02) \\
1.44(0.02)\end{array}$ & $\begin{array}{l}59.9(0.7) \\
27.7(2.4) \\
19.7(0.7)\end{array}$ & $\begin{array}{l}1.39(0.04) \\
1.40(0.05) \\
1.43(0.03)\end{array}$ & $\begin{array}{l}49.3(1.0)^{* * *} \\
29.3(0.8) \\
21.1(0.6)^{*}\end{array}$ \\
\hline Saginaw, MI & $\begin{array}{c}0-20 \\
25-50 \\
50-100\end{array}$ & $\begin{array}{l}- \\
- \\
-\end{array}$ & $\begin{array}{l}- \\
-\end{array}$ & $\begin{array}{l}1.32(0.03) \\
1.56(0.02) \\
1.54(0.05)\end{array}$ & $\begin{array}{l}42.5(0.6) \\
23.6(0.2) \\
24.9(0.2)\end{array}$ \\
\hline $\begin{array}{l}\text { Kellogg Biological } \\
\text { Station, MI }\end{array}$ & $\begin{array}{c}0-20 \\
25-50 \\
50-100\end{array}$ & $\begin{array}{l}1.25(0.02) \\
1.55(0.06) \\
1.64(0.03)\end{array}$ & $\begin{array}{r}46.3(4.2) \\
15.1(1.5) \\
6.2(0.6)\end{array}$ & $\begin{array}{l}1.44(0.04) \\
1.55(0.08) \\
1.48(0.12)\end{array}$ & $\begin{array}{c}30.5(1.5)^{* *} \\
8.5(0.3)^{*} \\
9.5(1.4)\end{array}$ \\
\hline Hoytville, OH & $\begin{array}{c}0-20 \\
25-50 \\
50-100\end{array}$ & $\begin{array}{c}1.10(0.01) \\
1.58(0.02) \\
\text { nd }\end{array}$ & $\begin{array}{c}96.5(1.1) \\
29.4(0.7) \\
\text { nd }\end{array}$ & $\begin{array}{l}1.37(0.03) \\
1.58(0.04) \\
1.52(0.05)\end{array}$ & $\begin{array}{l}48.7(2.5)^{* * *} \\
32.3(0.9) \\
32.2(0.6)\end{array}$ \\
\hline Wooster, OH & $\begin{array}{r}0-20 \\
25-50 \\
50-80\end{array}$ & $\begin{array}{c}1.30(0.03) \\
1.47(0.01) \\
\text { nd }\end{array}$ & $\begin{array}{l}56.9(0.9) \\
15.2(1.4) \\
\text { nd }\end{array}$ & $\begin{array}{l}1.39(0.06) \\
1.48(0.01) \\
1.75(0.02)\end{array}$ & $\begin{array}{c}25.4(2.3)^{* * *} \\
22.3(2.4)^{* *} \\
8.9(0.3)\end{array}$ \\
\hline South Charleston, OH & $\begin{array}{c}0-20 \\
25-50 \\
50-100\end{array}$ & - & $\begin{array}{l}- \\
-\end{array}$ & $\begin{array}{l}1.44(0.04) \\
1.56(0.03) \\
1.64(0.04)\end{array}$ & $\begin{array}{l}31.7(1.8) \\
21.0(0.8) \\
32.8(2.0)\end{array}$ \\
\hline Lexington, $\mathrm{KY}$ & $\begin{array}{r}0-20 \\
25-50 \\
50-80\end{array}$ & $\begin{array}{c}1.24(0.04) \\
1.43(0.02) \\
\text { nd }\end{array}$ & $\begin{array}{c}58.7(2.2) \\
24.0(1.2) \\
\text { nd }\end{array}$ & $\begin{array}{l}1.28(0.02) \\
1.43(0.03) \\
1.36(0.05)\end{array}$ & $\begin{array}{l}30.7(0.5)^{* * *} \\
12.5(0.2)^{* * *} \\
10.8(0.2)\end{array}$ \\
\hline
\end{tabular}

*,**,*** Means were significantly different from the noncultivated site at the $0.05,0.01$, and 0.001 levels of probability.

$\dagger$ Noncultivated site is located at Brownton, MN.

Standard error of the means are in parentheses. nd is not determined.

Hoytville, $\mathrm{OH}$ is unknown, but reduced decomposition (O'Brien and Stout, 1978) and movement of organic matter (Volkoff and Cerri, 1987) are plausible explanations.

The change in $\delta{ }^{13} \mathrm{C}$ of all depths of the cultivated soils relative to the native soils reflects the corn ${ }^{13} \mathrm{C}$ inputs (Table 6). The Ap horizon (0-20 cm) showed an average increase of $3 \%$ above the noncultivated, with a high of $5.2 \%$ at Wooster, OH. Although the KBS, MI site had only been in a corn monoculture for $8 \mathrm{yr}$, the 0 - to 20-cm depth increment had a similar change in $\delta$ ${ }^{13} \mathrm{C}$ as sites that had been cropped continuously to corn for 21 to $35 \mathrm{yr}$. During the $8 \mathrm{yr}$ period of continuous corn, $54 \mathrm{Mg} \mathrm{C}_{4}-\mathrm{C} \mathrm{ha}^{-1}$ were incorporated as residue, roots, and weeds, compared with an average of $176 \mathrm{Mg}$ $\mathrm{C}_{4}-\mathrm{C} \mathrm{ha}^{-1}$ among the other sites during a $30-\mathrm{yr}$ period. Before 1985, the KBS site had been in several rotations that included corn. We estimated that eight corn crops were grown between 1960 and 1985 and would have incorporated another $54 \mathrm{Mg} \mathrm{C}_{4}-\mathrm{C} \mathrm{ha}^{-1}$ prior to the

Table 5. Variations in $\delta{ }^{13} \mathrm{C}$ values of forest and corn stover.

\begin{tabular}{lc}
\hline Litter & \\
\hline Forest & $\delta{ }^{13} \mathrm{C}$ \\
Oak leaves & -27.5 \\
Oak bark & -26.5 \\
$\quad$ Mean & -27.0 \\
Corn stover & \\
$\quad$ Kellogg Biological Station, MI & $-12.3(0.1) \dagger$ \\
Wooster, OH & $-12.1(0.2)$ \\
Hoytville, OH & $-12.4(0.2)$ \\
$\quad$ Lamberton, MN $¥$ & -12.0 \\
$\quad$ Mean & $-12.3(0.3)$ \\
\hline
\end{tabular}

$\dagger$ Standard deviations in parentheses.

$\ddagger$ Value obtained from Huggins et al. (1997). corn monoculture. Including this additional $\mathrm{C}_{4}-\mathrm{C}$ would partially explain the similarity of change in $\delta{ }^{13} \mathrm{C}$ observed between KBS and the other sites. Another explanation lies in the coarse-textured nature of the soil at

Table 6. $8{ }^{13} \mathrm{C}$ for the 0 - to $20-, 25-$ to $50-$, and $50-$ to $100-\mathrm{cm}$ depth increments of noncultivated and cultivated sites.

\begin{tabular}{|c|c|c|c|}
\hline Site & Depth & Noncultivated & Cultivated \\
\hline & $\mathbf{c m}$ & \multicolumn{2}{|c|}{$-\delta^{13} \mathrm{C}$} \\
\hline Lamberton, $\mathbf{M N} \dagger$ & $\begin{array}{c}0-20 \\
25-50 \\
50-100\end{array}$ & $\begin{array}{l}-19.5 \div \\
-19.1 \\
-19.8\end{array}$ & $\begin{array}{l}-16.6^{* * *} \\
-16.1^{* * * *} \\
-19.3^{*}\end{array}$ \\
\hline Arlington, $\mathbf{W I}$ & $\begin{array}{c}0-20 \\
25-50 \\
50-100\end{array}$ & $\begin{array}{l}-17.6 \\
-17.0 \\
-18.2\end{array}$ & $\begin{array}{l}-15.8^{* * * *} \\
-15.2^{* * *} \\
-17.2^{*}\end{array}$ \\
\hline Saginaw, MI & $\begin{array}{c}0-20 \\
25-50 \\
50-100\end{array}$ & $\begin{array}{l}\text { nd } \\
\text { nd } \\
\text { nd }\end{array}$ & $\begin{array}{l}-23.8(0.3) \\
-25.2(0.1) \\
-25.8(0.1)\end{array}$ \\
\hline $\begin{array}{l}\text { Kellogg Biological } \\
\text { Station, MI }\end{array}$ & $\begin{array}{c}0-20 \\
25-50 \\
50-100\end{array}$ & $\begin{array}{l}-26.1 \\
-24.9 \\
-24.3\end{array}$ & $\begin{array}{l}-23.1 * * * \\
-22.0 * * * \\
-22.7 * *\end{array}$ \\
\hline Hoytville, $\mathrm{OH}$ & $\begin{array}{l}0-20 \\
25-50 \\
50-100\end{array}$ & $\begin{array}{l}-25.0 \\
-25.3 \\
-26.3\end{array}$ & $\begin{array}{l}-22.1^{* * * *} \\
-24.2^{*} \\
-25.7^{*}\end{array}$ \\
\hline Wooster, $\mathrm{OH}$ & $\begin{array}{r}0-20 \\
25-50 \\
50-80\end{array}$ & $\begin{array}{l}-25.5 \\
-24.2 \\
-23.9\end{array}$ & $\begin{array}{l}-20.3^{* * *} \\
-22.1^{* * *} \\
-22.3^{* *}\end{array}$ \\
\hline South Charleston, OH & $\begin{array}{c}0-20 \\
25-50 \\
50-100\end{array}$ & $\begin{array}{l}\text { nd } \\
\text { nd } \\
\text { nd }\end{array}$ & $\begin{array}{l}-17.0(0.1) \\
-20.8(0.1) \\
-22.0(0.5)\end{array}$ \\
\hline Lexington, KY & $\begin{array}{r}0-20 \\
25-50 \\
50-80 \\
\end{array}$ & $\begin{array}{l}-23.7 \\
-22.6 \\
-22.6 \\
\end{array}$ & $\begin{array}{l}-21.0^{* * *} \\
-21.5^{* * *} \\
-21.9 * *\end{array}$ \\
\hline
\end{tabular}

$*, * *, * * *$ Means were significantly different from the noncultivated site at the $0.05,0.01$, and 0.001 levels of probability.

$\dagger$ The noncultivated site is located at Brownton, $M N$.

$\ddagger$ nd is not determined. Standard error of the means are in $<0.2 \%$ for all measurements. 
Table 7. Estimates of $\mathrm{C}_{4}-\mathrm{C}$ corn residues remaining in the 0 - to 20-, 25- to 50-, and 50- to 100-cm depth increments after long-term corn monoculture.

\begin{tabular}{|c|c|c|c|c|c|}
\hline Site & Depth & $\begin{array}{l}\text { SOM-C from } \\
\text { crop residues } \dagger\end{array}$ & $\begin{array}{c}\text { Soil } \\
\mathrm{C}_{\tau}-\mathrm{C} \neq\end{array}$ & $\begin{array}{c}\text { Residue } \\
\text { input }\end{array}$ & $\begin{array}{c}\text { Residue } \\
\text { remaining } \\
\end{array}$ \\
\hline & $\mathbf{c m}$ & & \multicolumn{2}{|c|}{$-\mathrm{Mg} \mathrm{C} \mathrm{ha}^{-1}$} & $\%$ \\
\hline Lamberton, $\mathbf{M N}$ & $\begin{array}{c}0-20 \\
25-50 \\
50-100 \\
\text { Profile: }\end{array}$ & $\begin{array}{c}39.6(0.9) \S \\
35.8(1.0) \\
3.9(1.0) \\
-\end{array}$ & $\begin{array}{r}18.5(0.4) \\
11.5(0.4) \\
1.3(0.3) \\
31.3\end{array}$ & 188.2 & 16.6 \\
\hline Arlington, WI & $\begin{array}{c}0-20 \\
25-50 \\
50-100 \\
\text { Profile: }\end{array}$ & $\begin{array}{c}32.7(0.9) \\
35.0(0.9) \\
17.6(0.3) \\
-\end{array}$ & $\begin{array}{r}16.1(0.4) \\
10.3(0.3) \\
3.7(0.1) \\
30.1\end{array}$ & 250.2 & 12.0 \\
\hline Saginaw, MIII & $\begin{array}{c}0-20 \\
25-50 \\
50-100 \\
\text { Profile: }\end{array}$ & $\begin{array}{c}27.0(1.9) \\
10.0(1.0) \\
2.5(0.2) \\
-\end{array}$ & $\begin{array}{r}11.5(0.8) \\
2.4(0.3) \\
0.6(0.1) \\
14.5\end{array}$ & 106.2 & 13.7 \\
\hline $\begin{array}{l}\text { Kellogg Biological } \\
\text { Station, MII\# }\end{array}$ & $\begin{array}{c}0-20 \\
25-50 \\
50-100 \\
\text { Profile: }\end{array}$ & $\begin{array}{c}36.3(2.7) \\
22.4(0.4) \\
12.7(1.1) \\
-\end{array}$ & $\begin{array}{r}11.1(0.8) \\
3.1(0.3) \\
1.2(0.1) \\
15.4\end{array}$ & 108.6 & 14.2 \\
\hline Hoytville, OH & $\begin{array}{l}0-20 \\
25-50 \\
50-100 \\
\text { Profile: }\end{array}$ & $\begin{array}{c}22.1(0.6) \\
8.3(1.0) \\
3.6(0.4) \\
-\end{array}$ & $\begin{array}{r}10.8(0.3) \\
2.7(0.3) \\
1.2(0.1) \\
14.7\end{array}$ & 225.8 & 6.4 \\
\hline Wooster, $\mathbf{O H}$ & $\begin{array}{l}\text { 0-20 } \\
25-50 \\
50-80 \\
\text { Profile: }\end{array}$ & $\begin{array}{c}38.3(0.5) \\
17.3(1.6) \\
13.4(0.3) \\
-\end{array}$ & $\begin{array}{r}9.7(0.1) \\
3.9(0.4) \\
1.2(0.1) \\
14.8\end{array}$ & 200.9 & 7.4 \\
\hline South Charleston, $\mathrm{OH}$ & $\begin{array}{l}\mathbf{0 - 2 0} \\
25-50 \\
\text { 50-100 } \\
\text { Profile: }\end{array}$ & $\begin{array}{c}35.1(0.3) \\
20.4(0.5) \\
14.7(1.9) \\
-\end{array}$ & $\begin{array}{r}11.1(0.1) \\
4.3(0.1) \\
4.8(0.6) \\
20.2\end{array}$ & 227.2 & 11.3 \\
\hline Lexington, $\mathrm{KY}$ & $\begin{array}{c}0-20 \\
25-50 \\
50-80 \\
\text { Profile: }\end{array}$ & $\begin{array}{c}23.1(0.6) \\
10.4(0.3) \\
6.4(0.2) \\
-\end{array}$ & $\begin{array}{l}7.1(0.2) \\
1.3(0.1) \\
0.7(0.1) \\
9.1\end{array}$ & 166.3 & 5.5 \\
\hline
\end{tabular}

$\dagger$ Percentage of $\mathrm{C}$ derived from corn $=\left(\delta^{13} \mathrm{C}\right.$ cropped soil $-\delta^{{ }^{13}} \mathrm{C}$ native soil $) /\left(\delta^{13} \mathrm{C}\right.$ crop residue $-\delta^{13} \mathrm{C}$ native soil $)$.

\# The amount of incorporated corn, root, and $\mathrm{C}_{4}-\mathrm{C}$ weed residues remaining within individual depth increments and total soil profile. Values shown for the soil profile assume a uniform distribution of incorporated crop and root residues.

II ${ }^{13} \mathrm{C}$ of native soil assumed as $-26 \%$

$\$$ Standard error of the mean in parentheses.

\# Values at KBS are based on $C_{r}-C$ inputs from 1960 to 1993.

this site that exhibits a faster turnover of SOC $(\mathrm{H}$. Collins, 1998, unpublished data).

\section{$\mathbf{C}_{4}$-Derived Carbon}

The effect of changing from $\mathrm{C}_{3}$ to $\mathrm{C}_{4}$ vegetation was reflected in estimates of the amount of SOC derived from corn residues (Table 7). The change in percentage of SOC derived from corn is an indication of the SOC turnover rate as well as the potential to store $\mathrm{C}$. The majority of this $C$ was present in the surface $20 \mathrm{~cm}$, declining to an average of $9 \%$ at the $50-$ to $100-\mathrm{cm}$ depth. Thirty years of corn at Arlington, WI and Lamberton, $\mathrm{MN}$ resulted in an average replacement of $36 \%$ of the SOC by $\mathrm{C}_{4}-\mathrm{C}$ in the upper $50 \mathrm{~cm}$ of the soil profile. The remainder represented old $\mathrm{C}$ from the original prairie. The original $\mathrm{C}$ consisted of $53 \% \mathrm{C}_{3}-\mathrm{C}$ and $47 \% \mathrm{C}_{4}-\mathrm{C}$. After $30 \mathrm{yr}, 220 \mathrm{Mg} \mathrm{C}-\mathrm{C} \mathrm{ha}^{-1}$ had been added, an average of $31 \mathrm{Mg} \mathrm{C}_{4}-\mathrm{C} \mathrm{ha}^{-1}$ remained in the soil. This represented an incorporation efficiency of $14 \%$ of $\mathrm{C}_{4}-\mathrm{C}$ into the SOC to $1 \mathrm{~m}$. The percentage of SOC derived from corn across the site network dropped from a range of 23 to $40 \%$ at the surface to 4 to $15 \%$ at the $50-$ to $100-\mathrm{cm}$ depth. This leads us to believe that when the subsoils are $\mathrm{C}$ dated they will be thousands of years old. The value for the percentage of SOC derived from crop residues is affected by the total SOC present. Estimates of soil $\mathrm{C}$ storage capacities are shown in Table 7 when $\mathrm{C}_{4}-\mathrm{C}$ is expressed as $\mathrm{Mg} \mathrm{C} \mathrm{ha}^{-1}$. Knowledge of $C$ inputs allowed us to calculate the amount of residue remaining. This was very different at the various sites showing us that we cannot use regional values in our global change models.

In subsoil horizons, SOC would be derived mainly from roots (Van Veen et al., 1991). Few studies have determined the stabilization of root $\mathrm{C}$ into SOC below the Ap horizon. Reported estimates range from 11 to $18 \%$ for aboveground corn residues and 18 to $23 \%$ for root C (Larson et al., 1972; Barber, 1979). Studies of small grains show similar incorporation efficiencies (Buyanovsky and Wagner, 1987; Xu and Juma, 1993). Buyanovsky and Wagner (1987) found that $16 \%$ of straw C and $24 \%$ of root $\mathrm{C}$ was transferred into SOC using ${ }^{14} \mathrm{C}$ as a tracer. The lack of incorporation of $\mathrm{C}_{4}-\mathrm{C}$ into the deep layers of our soils could be due to less stabilization at depth because of less soil aggregation and lower humification rates. We attribute the very low values for SOC derived from $\mathrm{C}_{4}$-corn plants in the Saginaw and Hoytville soils to a lack of roots in a generally water-saturated layer below the depth of the drainage tiles. 
Table 8. Estimates of decomposition rates for $\mathrm{C}_{5}-\mathrm{C}$ soil organic matter as a function of changes in the natural abundance of $\delta^{13} \mathrm{C}$ in soil for the 0- to 20-, 25- to 50-, and 50- to 100-cm depth increments now under $\mathrm{C}_{4} \mathrm{corn}$.

\begin{tabular}{|c|c|c|c|c|c|c|}
\hline Site & Depth & $t$ & $\boldsymbol{A}_{0}^{\dagger}$ & $A_{\mathrm{t}}$ & $-\boldsymbol{k}$ & ${ }^{13} \mathbf{C ~ M R T}$ \\
\hline & cm & yr & \multicolumn{2}{|c|}{$\longrightarrow \mathrm{Mg} \mathrm{C} \mathrm{ha}^{-1} \ldots$} & & yr \\
\hline Lamberton, MN & $\begin{array}{c}0-20 \\
25-50 \\
50-100\end{array}$ & 33 & $\begin{array}{l}29.0(-) \neq \\
27.2(1.8) \\
17.9(1.7)\end{array}$ & $\begin{array}{l}28.3(3.0) \\
21.0(1.9) \\
15.7(0.3)\end{array}$ & $\begin{array}{l}-0.01070 \\
-0.00800 \\
-0.00412\end{array}$ & $\begin{array}{r}96(14) \\
125(14) \\
243(40)\end{array}$ \\
\hline Arlington, WI & $\begin{array}{c}0-20 \\
25-50 \\
50-100\end{array}$ & 35 & $\begin{array}{c}22.6(-) \\
9.4(0.4) \\
8.9(0.4)\end{array}$ & $\begin{array}{r}14.8(0.5) \\
6.7(0.3) \\
7.8(0.4)\end{array}$ & $\begin{array}{l}-0.01218 \\
-0.00952 \\
-0.00355\end{array}$ & $\begin{array}{c}82(7) \\
105(16) \\
282(50)\end{array}$ \\
\hline Saginaw, MI & $\begin{array}{c}0-20 \\
25-50 \\
50-100\end{array}$ & 21 & $\begin{array}{l}42.1(-) \\
23.6(0.2) \\
24.9(0.3)\end{array}$ & $\begin{array}{l}31.0(1.2) \\
21.2(0.7) \\
24.3(0.3)\end{array}$ & $\begin{array}{r}-0.01700 \\
-0.00476 \\
-0.00130\end{array}$ & $\begin{array}{c}60(7) \\
210(50) \\
769(24)\end{array}$ \\
\hline KBS, MI & $\begin{array}{c}0-20 \\
25-50 \\
50-100\end{array}$ & 8 & $\begin{array}{r}30.5(2.2) \\
8.5(0.5) \\
10.1(2.7)\end{array}$ & $\begin{array}{r}19.5(2.6) \\
6.6(0.4) \\
8.8(2.1)\end{array}$ & $\begin{array}{l}-0.05683 \\
-0.03180 \\
-0.01608\end{array}$ & $\begin{array}{l}18(3) \\
31(1) \\
62(9)\end{array}$ \\
\hline Hoytville, OH & $\begin{array}{c}0-20 \\
25-50 \\
50-100\end{array}$ & 31 & $\begin{array}{l}59.8(-) \\
32.4(2.2) \\
32.2(1.1)\end{array}$ & $\begin{array}{l}38.0(3.2) \\
29.7(2.6) \\
31.1(1.3)\end{array}$ & $\begin{array}{l}-0.01473 \\
-0.00262 \\
-0.00132\end{array}$ & $\begin{array}{r}70(13) \\
381(96) \\
756(64)\end{array}$ \\
\hline Wooster, OH & $\begin{array}{c}0-20 \\
25-50 \\
50-100\end{array}$ & 31 & $\begin{array}{r}37.2(-) \\
25.0(3.8) \\
8.9(0.3)\end{array}$ & $\begin{array}{r}15.7(2.2) \\
20.6(2.3) \\
7.7(0.2)\end{array}$ & $\begin{array}{l}-0.02806 \\
-0.00615 \\
-0.00465\end{array}$ & $\begin{array}{c}37(7) \\
163(36) \\
215(9)\end{array}$ \\
\hline South Charleston, OH & $\begin{array}{c}0-20 \\
25-50 \\
50-100\end{array}$ & 31 & $\begin{array}{l}31.7(2.5) \\
21.0(1.1) \\
34.8(2.9)\end{array}$ & $\begin{array}{l}19.8(1.7) \\
16.7(0.7) \\
29.7(2.5)\end{array}$ & $\begin{array}{l}-0.01518 \\
-0.0073 \\
-0.00516\end{array}$ & $\begin{array}{c}66(2) \\
137(7) \\
194(53)\end{array}$ \\
\hline Lexington, $\mathbf{K Y}$ & $\begin{array}{c}0-20 \\
25-50 \\
50-100\end{array}$ & 23 & $\begin{array}{l}42.3(-) \\
13.8(0.3) \\
12.8(0.3)\end{array}$ & $\begin{array}{r}23.6(0.6) \\
12.3(0.3) \\
6.4(0.2)\end{array}$ & $\begin{array}{l}-0.02530 \\
-0.00479 \\
-0.00286\end{array}$ & $\begin{array}{c}40(2) \\
209(9) \\
350(13)\end{array}$ \\
\hline
\end{tabular}

$\uparrow A_{t}=A_{0}\left(\exp ^{-k t}\right)$, where $A_{0}$ is the total $C_{5}-C$ prior to conversion to $C_{4}$ corn, $A_{1}$ is the proportion of $C_{5}-C$ remaining at the time $(t)$ of sampling, $k$ is the decay constant, and MRT is the mean residence time $(1 / k)$. Values of $A_{0}$ for the 0 - to $20-\mathrm{cm}$ depth increment are initial $C_{5}-C$ contents at the start of the long-term field studies and were obtained from Paul et al. (1997).

‡(-) sample variation not reported.

In our study, the length of time that soils were cropped to corn accounted for $47 \%$ of the variation $(P=0.014)$ in the amount of $\mathrm{C}_{4}-\mathrm{C}$ sequestered. Factors other than time are involved in $\mathrm{C}$ sequestration, but the interactions among them are complex (Parton et al., 1987). The high clay Saginaw soil showed high $\mathrm{C}_{4}$ residue sequestration similar to the other sites high in SOC such as Lamberton, MN. Hoytville also high in clay was among the lowest in $\mathrm{C}_{4}$ sequestration, again indicating that other site-specific factors also play a role in $\mathrm{C}$ sequestration.

\section{Turnover of Soil Organic Carbon}

Knowledge of the proportion of $\mathrm{C}_{4}-\mathrm{C}$ present and estimations for the soil $\mathrm{C}$ present before the initiation $\left(A_{0}\right)$ of the continuous corn treatment allowed us to calculate the concentration of non-corn $C\left(\mathrm{C}_{3}\right)$ at the time of sampling $\left(A_{1}\right)$. From this we calculated $\mathrm{C}_{3}$ mean residence times (MRT $=1 / k)$ by assuming an exponential decay of the SOC present in each soil horizon (Table 8). The ${ }^{13} \mathrm{C}_{3}$ MRT of the Ap horizon was $96 \mathrm{yr}$ at Lamberton, $\mathrm{MN}$ and $83 \mathrm{yr}$ at Arlington, WI (Table 8). These increased to $243 \mathrm{yr}$ for the $50-$ to $100-\mathrm{cm}$ depth at Lamberton and 282 yr at Arlington.

Mean residence times for the $\mathrm{C}_{3}-\mathrm{C}$ in the Ap horizons of cultivated forested sites ranged from $18 \mathrm{yr}$ at KBS, MI to $70 \mathrm{yr}$ at Hoytville, OH. Below the Ap, MRTs increased with depth ranging from 137 to $381 \mathrm{yr}$ in the $25-$ to $50-\mathrm{cm}$ and 210 to $769 \mathrm{yr}$ in the $50-$ to $100-\mathrm{cm}$ depth. The longer MRTs at Saginaw, MI and Hoytville, $\mathrm{OH}$ are probably related to the protection of SOC by clay in these fine-textured soils. Yet among sites, the clay had not uniformly protected the $\mathrm{C}_{4}-\mathrm{C}$ that was more recently added (Table 7).
Huggins et al. (1998) suggested that longer MRTs in northern prairie soils were a function of cooler soil temperatures and poorly drained fine-textured soils that may inhibit decomposition rates. We observed this trend of longer MRTs at sites in the northern compared with the southern Corn Belt. Our analysis that allowed separation of $\mathrm{C}_{4^{-}}$and $\mathrm{C}_{3}-\mathrm{C}$ showed strong clay protection effects on the older $\mathrm{C}_{3}-\mathrm{C}$ (Table 8 ) but not on the younger $\mathrm{C}_{4}-\mathrm{C}$ (Table 7). There is a large body of literature supporting both the quantitative importance and resistant nature of SOC associated with primary soil particles (sand, silt, and clay) and organo-mineral fractions (micro- and macroaggregates) (Jenkinson, 1977; Anderson et al., 1981; Tiessen et al., 1984; Balesdent et al., 1988; Jastrow et al., 1996). Our results show that the complete answer is not yet known.

A potential source of error results from our assumption that corn residues incorporated before the start of the corn monoculture did not contribute significantly to the initial $\delta{ }^{13} \mathrm{C}$. We know that the cultivated soils had some corn residues incorporated during the $\approx 80 \mathrm{yr}$ of cultivation before the initiation of the corn monoculture $30 \mathrm{yr}$ ago. The much lower corn yields during the early periods of cultivation and the fact that there remains only 5 to $17 \%$ of the $\mathrm{C}_{4}-\mathrm{C}$ incorporated during the last 30 yr suggests that disregarding the early inputs, with exception of KBS, MI, would not greatly affect the calculated turnover times. The $18 \mathrm{yr}$ MRT of $\mathrm{C}_{3}-\mathrm{C}$ calculated for KBS was based on an 8-yr period of corn monoculture; however, there were at least eight corn crops grown between 1960 and 1985. If we recalculate the $\mathrm{C}_{3}-\mathrm{C}$ MRT on the basis of this additional information, we derive an estimate of $39 \mathrm{yr}$. Estimates of weed 
biomass could also contribute to some of the error in our calculations of $\mathrm{C}_{4}$ input since an unknown proportion of the weeds were probably $\mathrm{C}_{3}$ plants. Lowering or raising the inputs attributed to $\mathrm{C}_{4}$ weeds would only slightly affect the MRTs calculated in Table 8 .

\section{CONCLUSIONS}

The use of ${ }^{13} \mathrm{C}$ incorporation together with depth and bulk density analyses on long-term agronomic sites with known $\mathrm{C}$ inputs allowed us to calculate the proportion of $\mathrm{C}_{3}$ - and $\mathrm{C}_{4}-\mathrm{C}$ turnover and the percentage of crop residues remaining. The previously forested sites have lost as much $\mathrm{C}$ as those from the prairies. Improved drainage was a factor in those losses for soils that had been tiled. There is a major potential for enhanced soil $C$ storage by improved management under continued agriculture, by reversion to an uncultivated state, and by stopping drainage through tiles during the non-crop period. Return of these soils to even $75 \%$ of their original $\mathrm{C}$ levels has the promise of significant $\mathrm{C}$ storage in global change calculations. The soils in their native state change in ${ }^{13} \mathrm{C}$ content with depth but not in a consistent pattern. This does not affect calculations regarding soil $\mathrm{C}$ dynamics as long as representative deep soil samples are analyzed. The difference between soils in $\mathrm{C}_{4}$ residue remaining at depth reflects the rooting depth of corn in individual soils at the sites as well as soil physical and chemical factors that affect decomposition and humification.

The general similarities in $\mathrm{C}$ dynamics across sites give us confidence in the ${ }^{13} \mathrm{C}$ approach to developing concepts describing $\mathrm{C}$ storage across a range of soil types. The northern prairie soils have a greater potential for $\mathrm{C}$ storage and longer $\mathrm{C}_{3}$ turnover times than the previously forested sites. The clay effects are more important for old $\left(\mathrm{C}_{3}-\mathrm{SOC}\right)$ than for younger $\mathrm{C}_{4}$ material and are associated with chemical recalcitrance (Martel and Paul, 1974). We conclude that chemical effects (clay stabilization-humification and aromaticity) will strongly affect the turnover of the resistant SOC. Younger materials will be more dependent on soil management and physical factors such as aggregation.

There is further need to develop more accurate soil parameters for modeling scenarios that are refined enough for calculation of long-term soil sustainability and global change. The ${ }^{13} \mathrm{C}$ approach where there has been a $\mathrm{C}_{3}$ to $\mathrm{C}_{4}$ plant switch is best used in conjunction with other available approaches. Soil from this sequence of sites has been analyzed using acid hydrolysis and $\mathrm{C}$ dating to determine the size of the resistant SOM. Extended laboratory incubations together with ${ }^{13} \mathrm{CO}_{2}$ analyses are used to determine the pool sizes and fluxes of the active and slow C pools ( $\mathrm{H}$. Collins, 1998, personal communication). A discussion of the overall soil dynamics and modeling inputs is thus best left to future studies

\section{ACKNOWLEDGMENTS}

The soil samples were obtained from an EPA funded project: Ecosystem Carbon Pools and Dynamics, with E.T. Elliott, K. Paustian, and C.V. Cole of Colorado State University. The work was conducted under the auspices of the U.S. Department of Energy grant: The Measurement of Pool sizes and Flux Rates of Soil Carbon Fractions. We thank D. Harris for mass spectrometer analyses and K. Martin for technical assistance in processing samples. KBS contribution no. 851.

\section{REFERENCES}

Agren, G.I., E. Bosatta, and J. Balesdent. 1996. Isotope discrimination during decomposition of organic matter. A theoretical analysis. Soil Sci. Soc. Am. J. 60:1121-1126.

Anderson, D.W., S. Saggar, J.R. Bettany, and J.W.B. Stewart. 1981. Particle size fractions and their use in studies of soil organic matter. The nature and distribution of forms of carbon, nitrogen, and sulfur. Soil Sci. Soc. Am. J. 45:767-711.

Balesdent, J., and M. Balabane. 1992. Maize root-derived soil organic carbon estimated by natural ${ }^{13} \mathrm{C}$ abundance. Soil Biol. Biochem. 24:97-101.

Balesdent, J., C. Girardin, and A. Mariotti. 1993. Site-related $\delta{ }^{13} \mathrm{C}$ of tree leaves and soil organic matter in a temperate forest. Ecology 74:1713-1721.

Balesdent, J., and A. Mariotti. 1996. Measurements of soil organic matter turnover using ${ }^{13} \mathrm{C}$ natural abundance. p. 83-112. In T.W. Boutton and S. Yamasaki (ed.) Mass spectrometry of soils. Marcel Dekker, New York.

Balesdent, J., G.H. Wagner, and A. Mariotti. 1988. Soil organic matter turnover in long-term field experiments as revealed by carbon-13 natural abundance. Soil Sci. Soc. Am. J. 52:118-124.

Barber, S.A. 1979. Corn residue management and soil organic matter. Agron. J. 71:625-627.

Boutton, T.W. 1996. Stable carbon isotope ratios of soil organic matter and their use as indicators of vegetation and climate change. $p$. 47-82. In T.W. Boutton and S. Yamasaki (ed.) Mass spectrometry of soils. Marcel Dekker, New York.

Buyanovsky, G.A., and G.H. Wagner. 1987. Carbon transfer in a winter wheat (Triticum aestivum) ecosystem. Biol. Fertil. Soils 5:76-82.

Buyanovsky, G.A., C.L. Kucera, and G.H. Wagner. 1987. Comparative analyses of carbon dynamics in native and cultivated ecosystems. Ecology 68:2023-2031.

Buyanovsky, G.A., and G.H. Wagner. 1997. Crop residue input to soil organic matter in Sanborn Field. p. 73-84. In E.A. Paul et al. (ed.) Soil organic matter in temperate agroecosystems: Long-term experiments in North America. CRC Press, Boca Raton, FL.

Cerri, C.C., and F. Andreux. 1990. Changes in organic matter content in Oxisols cultivated with sugar cane and pasture. Studies on ${ }^{13} \mathrm{C}$ natural abundance measurement. Trans. 14th International. Congress of Soil Sci., Kyoto, IV:98-103.

Christenson, D.R. 1997. Soil organic matter in sugar beet and dry bean cropping systems in Michigan. p. 151-160. In E.A. Paul et al. (ed.) Soil organic matter in temperate agroecosystems: Longterm experiments in North America. CRC Press, Boca Raton, FL.

Dick, W.A., W.M. Edwards, and E.L. McCoy. 1997. Continuous application of no-tillage to Ohio soil: Changes in crop yields and organic matter-related soil properties. p. 171-182. In E.A. Paul et al. (ed.) Soil organic matter in temperate agroecosystems: Long-term experiments in North America. CRC Press, Boca Raton, FL.

Dzurec, R.S., T.W. Boutton, M.M. Caldwell, and B.N. Smith. 1985. Carbon isotope ratios of soil organic matter and their use in assessing community composition changes in Curlew Valley, Utah. Oecologia 66:17-24.

Flach, K.W., T.O. Barnwell, Jr., and P. Crosson. 1997. Impacts of agriculture on atmospheric carbon dioxide. p. 3-5. In E.A. Paul et al. (ed.) Soil organic matter in temperate agroecosystems: Longterm experiments in North America. CRC Press, Boca Raton, FL.

Follett, R.F., E.A. Paul, S.W. Leavitt, A.D. Halvorson, D. Lyon, and G.A. Peterson. 1997. Carbon isotope ratios of Great Plains soils and in wheat-fallow systems. Soil Sci. Soc. Am. J. 61:1068-1077.

Frye, W.W., and R.L. Blevins. 1997. Soil organic matter under longterm no-tillage and conventional tillage corn production in Kentucky. p. 227-234. In E.A. Paul et al. (ed.) Soil organic matter in temperate agroecosystems: Long-term experiments in North America. CRC Press, Boca Raton, FL. 
Galimov, E.M. 1985. The biological fractionation of isotopes. Academic Press, New York.

Greb, B.W. 1983. Water conservation: Central Great Plains. p. 57-72. In H.E. Dregne and W.O. Willis (ed.) Dryland agriculture. Agron. Monogr. 23. ASA, CSSA, and SSSA, Madison, WI.

Gregorich, E.G., B.H. Ellert, and C.M. Monreal. 1995. Turnover of soil organic matter and storage of corn residue carbon estimated from natural ${ }^{13} \mathrm{C}$ abundance. Can. J. Soil Sci. 75:161-167.

Gregorich, E.G., C.M. Monreal, M. Schnitzer, and H.-R. Schulten. 1996. Transformation of plant residues into soil organic matter: Chemical characterization of plant tissue, isolated soil fractions, and whole soils. Soil Sci. 161:680-693.

Guillet, B., P. Faivre, A. Mariotti, and J. Khobzi. 1988. The ${ }^{14} \mathrm{C}$ dates and ${ }^{13} \mathrm{C} /{ }^{12} \mathrm{C}$ ratios of soil organic matter as a means of studying the past vegetation in intertropical regions: Examples from Colombia (South America). Paleogeogr. Paleoclimatol. Paleoecol. 65:51-58.

Houghton, R.A., J.E. Hobbie, J.M. Melillo, B. Moore, B J. Peterson, G.R. Shaver, and G.M. Woodwell. 1983. Changes in the carbon content of terrestrial biota and soils between 1860 and 1980: Net release of $\mathrm{CO}_{2}$ to the atmosphere. Ecol. Monogr. 53:235-262.

Huggins, D.R., and D.J. Fuchs. 1997. Long-term N management effects on corn yield and soil $\mathrm{C}$ of an Aquic Haplustoll in Minnesota. p. 121-128. In E.A. Paul et al. (ed.) Soil organic matter in temperate agroecosystems: Long-term experiments in North America. CRC Press, Boca Raton, FL.

Huggins, D.R., C.E. Clapp, R.R. Allmaras, J.A. Lamb, and M.F. Layese. 1998. Dynamics of soil carbon in corn-soybean sequences as estimated from natural ${ }^{13} \mathrm{C}$ abundance. Soil Sci. Soc. Am. J. $62: 161-167$

Jastrow, J.D., T.W. Boutton, and R.M. Miller. 1996. Carbon dynamics of aggregate-associated organic matter estimated by carbon-13 natural abundance. Soil Sci. Soc. Am. J. 60:801-807.

Jenkinson, D.S. 1977. Studies of the decomposition of plant material in soil. V. The effects of plant cover and soil type on the loss of carbon from ${ }^{14} \mathrm{C}$ labelled ryegrass decomposing under field conditions. J. Soil Sci. 28:424-434.

Larson, W.E., C.E. Clapp, W.H. Pierre, and Y.B. Morashan. 1972 Effects of increasing amounts of organic residues on continuous corn. II. Organic carbon, nitrogen, phosphorus, and sulfur. Agron. J. 64:204-208.

Martel, Y.A., and E.A. Paul. 1974. Effects of cultivation on the organic matter of grassland soils as determined by fractionation and radiocarbon dating. Can. J. Soil Sci. 54:419-426.

Mary, B., A. Mariotti, and J.L. Morel. 1992. Use of ${ }^{13} \mathrm{C}$ variations in natural abundance for studying the biodegradation of root mucilages, roots, and glucose in soil. Soil Biol. Biochem. 24:1065-1077.

O'Brien, B.J., and J.D. Stout. 1978. Movement and turnover of soil organic matter as indicated by carbon isotope measurements. Soil Biol. Biochem. 10:309-317.

Parr, J.F., and R.I. Papendick. 1978. Factors affecting the decomposi- tion of crop residues by microorganisms. p. 101-129. In W.R. Oschwald (ed.) Crop residue management systems. ASA Spec. Publ. 31. ASA, CSSA, and SSSA, Madison, WI.

Parton, W.J., D.S. Schimel, C.V. Cole, and D.S. Ojima. 1987. Analysis of factors controlling soil organic matter levels in Great Plains grasslands. Soil Sci. Soc. Am. J. 51:1173-1179.

Paul, E.A., K.H. Paustian, E.T. Elliott, and C.V. Cole. 1997. Soil organic matter in temperate agroecosystems: Long-term experiments in North America. CRC Press, Boca Raton, FL.

Paustian, K., H.P. Collins, and E.A. Paul. 1997. Management controls on soil carbon. p. 15-50. In E.A. Paul et al. (ed.) Soil organic matter in temperate agroecosystems: Long-term experiments in North America. CRC Press, Boca Raton, FL.

Qian, J.H., and J.W. Doran. 1996. Available C released from crop roots during growth by carbon-13 natural abundance. Soil Sci. Soc. Am. J. 60:828-831.

Ryan, M.C., and R. Aravena. 1994. Combining ${ }^{13} \mathrm{C}$ natural abundance and fumigation extraction methods to investigate soil microbial biomass turnover. Soil Biol. Biochem. 26:1583-1585.

Stout, J.D., K.M. Goh, and T.A. Rafter. 1981. Chemistry and turnover of natural occuring resistant organic compounds in soil. p. 19-24 In E.A. Paul and J.N. Ladd (ed.) Soil biochemistry. Vol. 5. Marcel Dekker, New York.

Tiessen, H.J., J.W.B. Stewart, and H.W. Hunt. 1984. Concepts of soil organic matter transformations in relation to organo-mineral particle size fractions. Plant Soil 76:287-296.

Tieszen, L.L., and A.A. Steuter. 1991. Relationship between community isotope values and nutrient concentrations in a northern mixed prairie. Proc. S.D. Acad. Sci. 70:55-67.

van Kessel, C., R.E. Farrell, and P.J. Pennock. 1994. Carbon-13 and nitrogen-15 natural abundance in crop residues and soil organic matter. Soil Sci. Soc. Am. J. 58:382-389.

Van Veen, J.A., E. Liljeroth, and J.A. Lekkerkerk. 1991. Carbon fluxes in plant-soil systems at elevated atmospheric $\mathrm{CO}_{2}$ levels Ecol. Appl. 12:175-181.

Vanotti, M.B., L.G. Bundy, and A.E. Peterson. 1997. Nitrogen fertilization and legume-cereal rotation effects on soiI productivity and organic matter dynamics in Wisconsin. p. 105-120. In E.A. Paul et al. (ed.) Soil organic matter in temperate agroecosystems: Longterm experiments in North America. CRC Press, Boca Raton, FL.

Volkoff, B., and C.C. Cerri. 1987. Carbon isotopic fractionation in subtropical Brazilian grassland soils. Comparison with tropical forest soils. Plant Soil 102:27-31.

Wedin, D.A., L.L. Tieszen, B. Dewey, and J. Pastor. 1995. Carbon isotope dynamics during grass decomposition and soil organic matter formation. Ecology 76:1383-1392.

Xu, J.G., and N.G. Juma. 1993. Above- and below-ground transformation of photosynthetically fixed carbon by two barley (Hordeum vulgare L.) cultivars in a Typic Cryoborall. Soil Biol. Biochem. 25:1263-1272. 